\title{
Root vitality of Fagus sylvatica L., Quercus petraea Liebl. and Acer pseudoplatanus L. in mature mixed forest stand
}

\author{
Dorota Grygoruk
}

Forest Research Institute, Department of Forest Ecology, Sękocin Stary, Braci Leśnej 3, 05-090 Raszyn, Poland, phone: +48 22 7150414, e-mail: farfald@ibles.waw.pl

\begin{abstract}
The main task of the present study was to investigate the root vitality of common beech Fagus sylvatica L., sessile oak Quercus petraea Liebl. and sycamore maple Acer pseudoplatanus L. in the optimal growth conditions in south-western Poland. The study was carried out in 130-year-old mixed stand located within natural range of studied tree species. The density of roots $\left(\mathrm{g} / 100 \mathrm{~cm}^{3}\right.$ of soil) and biomass of fine roots $\left(\mathrm{g} / \mathrm{m}^{2}\right)$ in topsoil layers $(0-5 \mathrm{~cm}, 5-15 \mathrm{~cm})$ were determined in the tree biogroups of the same species. The mean total root density ranged from 0.248 to $0.417 \mathrm{~g} / 100 \mathrm{~cm}^{3}$ in the $0-5 \mathrm{~cm}$ soil layer, and it decreased in the deeper soil layer $(5-15 \mathrm{~cm})$. There were found no statistically significant differences of total root densities between tree biogroups in topsoil layers. Diversity of fine root biomass was comparable in the tree biogroups $\left(H^{\prime}=1.5\right)$, but common beech showed more intensive growth of fine roots in the topsoil $0-15 \mathrm{~cm}$ when compared to sessile oak and sycamore maple. The results of the study point out the stability of the multi-species structure of the mixed stand studied, and consequently - the ability of beech, sessile oak and sycamore maple trees to coexist in the mixed stands - in the area of natural range of these species.
\end{abstract}

\section{KeY WORDS}

root density, fine root biomass, common beech, sessile oak, sycamore maple

\section{INTRODUCTION}

The development of stands is closely connected with tree competition for environmental resources, especially light and water. The spatial heterogeneity of microhabitats considerably affects forest biological diversity. Availability of nutrients in forest soils, soil humidity and the amount of light accessible to stand lower layers, are decisive factors in tree species coexistence (Beckage and Clark 2003). More often, tree relationships in forest ecosystems have been studied on the basis the growth of aboveground parts than roots (Beyer et al. 2013). The majority of fine roots and mycorrhizas develops in the topsoil layers, where create a specific structural system functionally adjusted to absorption of nutrient and water uptake. The root systems througt its structure, vitality and species specificity modify the competition of trees between and within species (McClaugherty et al. 1982; Sanantonio and Hermann 1985; Macfall et al. 1991; Vogt et al. 1996; Leuschner et al. 2004).

The most important climatic factors that can limit the occurrence of forest tree species are the minimum 
winter temperature, high summer temperatures and precipitation (Stykes and Prentice 1995). In Poland there increases the importance of mixed stands as well as broadleaved species, including common beech $\mathrm{Fa}$ gus sylvatica L., sessile oak Quercus petraea Liebl. and sycamore maple Acer pseudoplatanus L. (Forests in Poland 2012). According to Brzeziecki (2000), the common beech and sessile oak use the mixed strategy to tolerate stress and competition as well as show high resistance to negative influence of biotic and abiotic factors. Sycamore maple uses a typical competitive strategy, it avoids regions with extreme climatic and soil conditions and is characterized a fast growth rate. Under favorable conditions, it can successfully compete the common beech, which is generally regarded as an exceptionally strong competitor.

Mixed stands play an important role in global warming mitigation, on account of their greater biodiversity as well as higher resistance to disturbances when compared to pure stands (IPCC 2007). The aim of the present study was to compare the root vitality of broadleaved trees, such as F. sylvatica, Q. petraea and A. pseudoplatanus, which are common in mixed forests in Europe and in Poland. The root density with special consideration of fine roots was analyzed in the topsoil layers $(0-5 \mathrm{~cm}, 5-15 \mathrm{~cm})$. The hypothesis of study was that the biogroups of mature trees differ significantly in the root density in the topsoil layers.

\section{MAterial AND Methods}

The study was carried out in 130-year-old mixed stand, which represented the optimal growth conditions of $F$. sylvatica, Q. petraea and A. pseudoplatanus within their natural range. The stand was located in southwestern Poland (Jawor Forest District - Fig. 1) on the border between the Legnicki and the Pogórze Kaczawskie nature mesoregions (Zielony and Kliczkowska 2012). The study area represented highland fresh forest on acidic brown soil. In September 2010, three biogroups of trees were selected based on the following criteria: species (Quercus, Fagus, Acer), the distance between trees no larger than $7.00 \mathrm{~m}$ and distribution of trees in the group (Mayer 1992). Around five trees in each biogroup, at the distance not bigger than $1.50 \mathrm{~m}$ from tree trunks, there were collected 5 soil samples with tree roots, using a soil corer $(8 \mathrm{~cm}$ diameter), from the topsoil layers $(0-5 \mathrm{~cm}, 5-15 \mathrm{~cm})$. At the same time root samples were taken as root standards for laboratory observations.

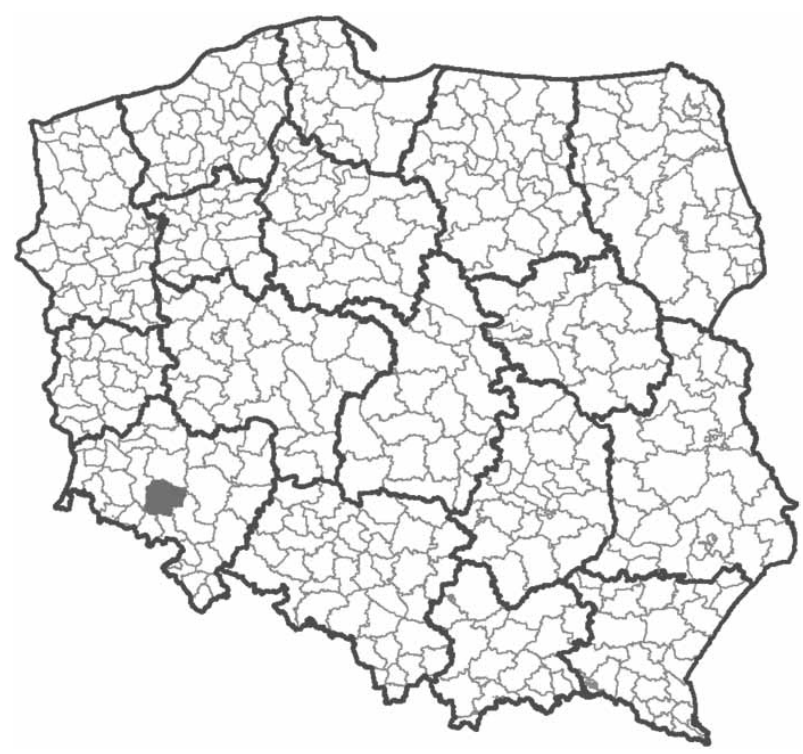

Figure 1. Location (the forest district) of the study area (htpp://web.pages)

Laboratory analyses were conducted consistent with the method described by Farfał (2011). Samples of roots were divided into 3 groups: live roots of the tree species studied, live roots of other species and dead roots (species not determined). The root vitality was characterized based on: the total root density ( $\mathrm{g} / 100 \mathrm{~cm}^{3}$ of soil), the root density according the diameter fractions (I: fine roots- the diameter $<2 \mathrm{~mm}$, II: $2-5 \mathrm{~mm}$, III: $5-10 \mathrm{~mm}$, IV: $>10 \mathrm{~mm}$ ), the fine root biomass $\left(\mathrm{g} / \mathrm{m}^{2}\right)$. The diversity of fine root biomass of the tree species studied was determined by the Shannon-Wiener index (1949):

$$
\mathrm{H}^{\prime}=-\Sigma p_{i} \cdot \ln \left(p_{i}\right)
$$

$p_{i}=n_{i} / N, \quad i=1,2,3, \ldots, S$

$n_{i}$ - fine root biomass of individual trees in the biogroup,

$N$ - total fine root biomass in the biogroup.

The climatic conditions of study area were characterized based on meteorological data (station 
Wrocław) for the years 2000-2010 (Bulletins of the State Hydrological and Meteorological Services Poland, 2000-2010). Atmospheric drought in the vegetation seasons 2000-2010 was appraised with the use of the hydrothermal index (Sielianinow 1966):

$$
K=10 P / t
$$

$P$ - sum of monthly precipitation,

$t-$ sum of daily temperatures in a given month.

The obtained data were tested by ANOVA and ANOVA rang Kruskal-Wallis (STATISTICA 10).

\section{Results}

\section{Total tree root density}

In the soil layer $0-5 \mathrm{~cm}$, the highest value of the total tree root density $\left(0.417 \mathrm{~g} / 100 \mathrm{~cm}^{3}\right.$ of soil) was measured in Fagus biogroup, and the lowest $\left(0.248 \mathrm{~g} / 100 \mathrm{~cm}^{3}\right.$ of soil) in Acer biogroup (Fig. 2). In the soil layer 5-15 cm, the least density of roots was observed in Quercus biogroup $\left(0.223 \mathrm{~g} / 100 \mathrm{~cm}^{3}\right.$ of soil), and the largest in Acer biogroup $\left(0.281 \mathrm{~g} / 100 \mathrm{~cm}^{3}\right.$ of soil). In both soil layers, the differences of root density between the biogroups were not statistically significant $(0-5 \mathrm{~cm}$ soil layer: $H=1.004, p=0.6051 ; 5-15 \mathrm{~cm}$ soil layer: $H=0.2396$, $p=0.8871)$.

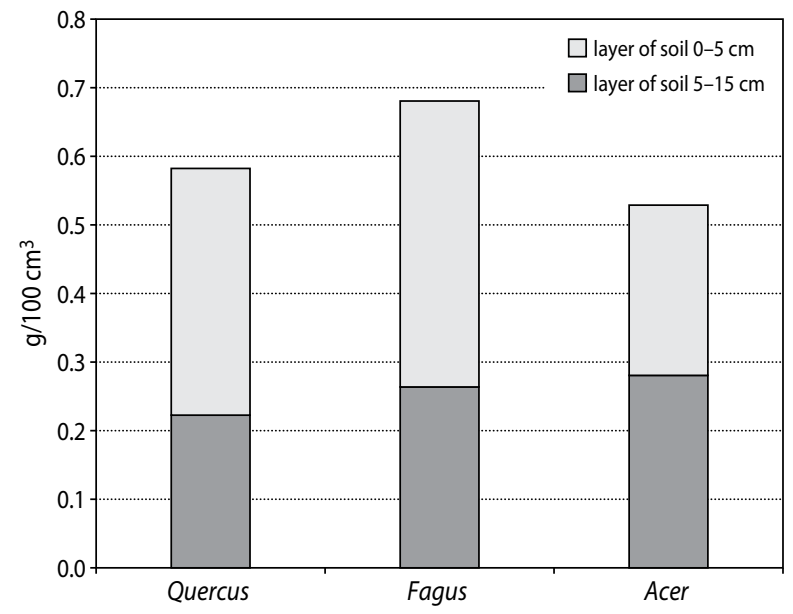

Figure 2. Mean total density of tree roots $\left(\mathrm{g} / 100 \mathrm{~cm}^{3}\right.$ of soil) depending on tree biogroup and soil layer

\section{Root density in the soil layer $\mathbf{0 - 5} \mathbf{c m}$}

In Quercus biogroup, fine roots were most abundant (39\%, mean density: $0.141 \mathrm{~g} / 100 \mathrm{~cm}^{3}$ of soil), whereas least roots (12\%; mean density: $0.044 \mathrm{~g} / 100 \mathrm{~cm}^{3}$ of soil) was categorized as IV fraction (>10 mm). In Fagus biogroup, the highest share was found roots $>10 \mathrm{~mm}(54 \%$, mean density: $0.227 \mathrm{~g} / 100 \mathrm{~cm}^{3}$ of soil), while the least roots $2-5 \mathrm{~mm}\left(12 \%\right.$, average density $0.049 \mathrm{~g} / 100 \mathrm{~cm}^{3}$ of soil). In Acer biogroup, there was observed the highest share $(51 \%)$ of fine roots with the mean density $0.127 \mathrm{~g} / 100 \mathrm{~cm}^{3}$ of soil. The density of roots $2-5 \mathrm{~mm}$ and 5-10 $\mathrm{mm}$ were comparable to Quercus biogroup (Fig. 3). The analysis of data on the root density between the tree biogroups showed no significant differences $(p>0.05)$.

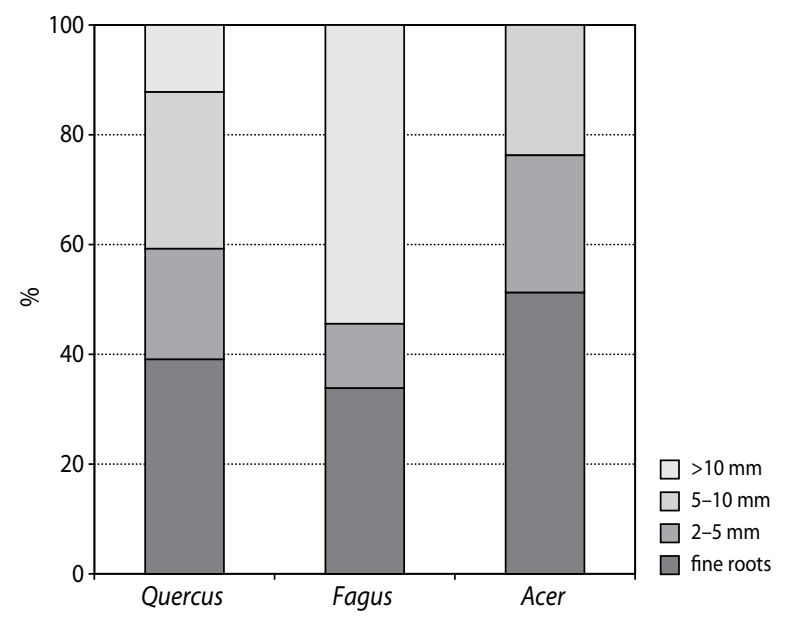

Figure 3. Proportions of root in the total density of tree roots depending on root diameter and tree biogroup $(0-5 \mathrm{~cm}$ soil layer)

\section{Root density in soil layer $5-15 \mathrm{~cm}$}

Beech trees showed the highest density of fine roots $\left(0.075 \mathrm{~g} / 100 \mathrm{~cm}^{3}\right.$ of soil), which the share was $28 \%$ (Fig. 4). The fine roots of oak and sycamore trees constituted $20 \%$, their the mean density was equal $0.045 \mathrm{~g} / 100 \mathrm{~cm}^{3}$ of soil and $0.058 \mathrm{~g} / 100 \mathrm{~cm}^{3}$ of soil, respectively. The differences of the fine root density between beech and oak trees were statistically significant $(p=0.0429)$. The share of roots $2-5 \mathrm{~mm}$ was comparable in the trees biogroups (25-30\%). The roots 5-10 $\mathrm{mm}$ were most abundant in Fagus biogroup (43\%), and roots $>10 \mathrm{~mm}$ - in Acer biogroup (27\%). The differences of the density of roots (II, III, IV frac- 
tion) observed between tree biogroups were not significant $(p>0.05)$.

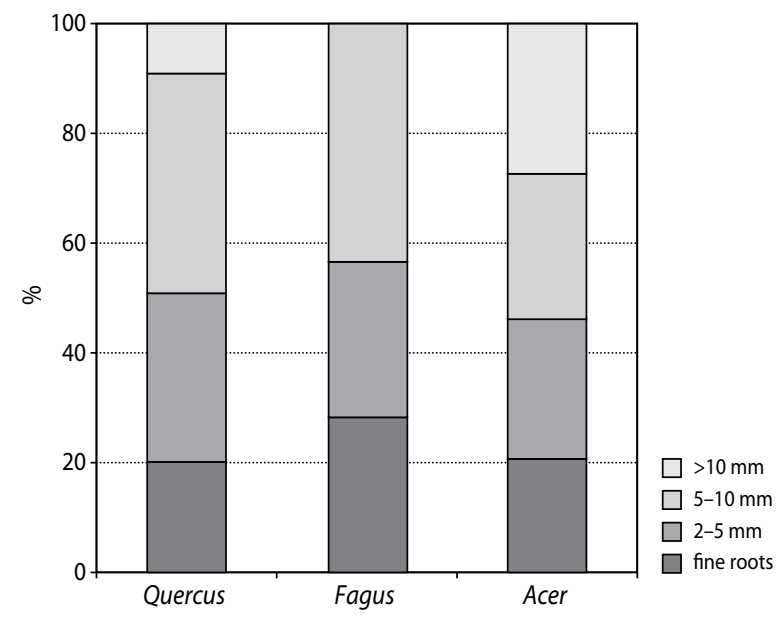

Figure 4. Proportions of root in the total density of tree roots depending on root diameter and tree biogroup $(5-15 \mathrm{~cm}$ soil layer)

\section{Fine root}

In tree biogroups, the fine roots of woody species were represented most abundantly $(48-64 \%)$ in $0-5 \mathrm{~cm}$ soil layer and (58-79\%) in 5-15 cm layer (Fig. 5 and 6).

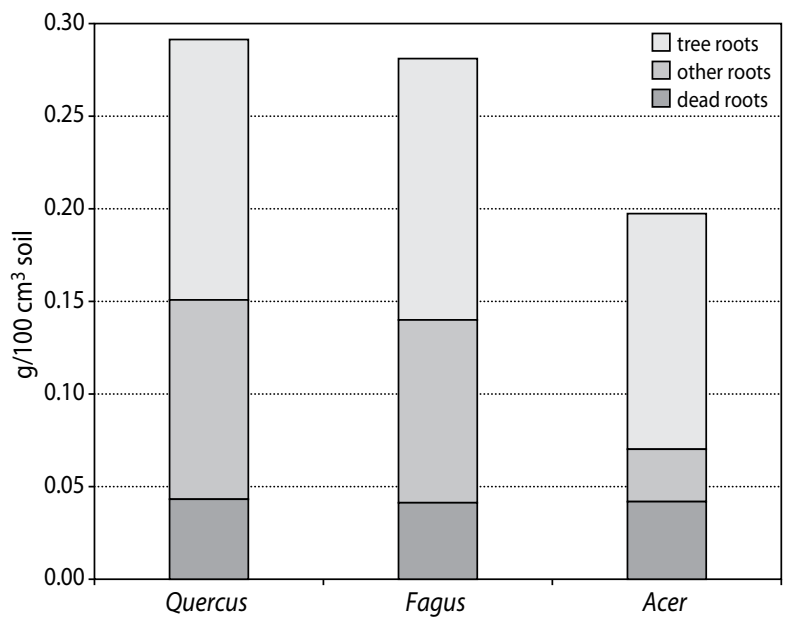

Figure 5. Mean fine root density $\left(\mathrm{g} / 100 \mathrm{~cm}^{3}\right.$ of soil) depending on tree biogroup ( $0-5 \mathrm{~cm}$ soil layer)

The mean fine root density of other species (other roots) was from $0.028 \mathrm{~g} / 100 \mathrm{~cm}^{3}$ of soil (Acer) to $0.108 \mathrm{~g} / 100 \mathrm{~cm}^{3}$ of soil (Quercus) in $0-5 \mathrm{~cm}$ soil layer and considerably decreased in $5-15 \mathrm{~cm}$ soil layer $\left(0.007-0.019 \mathrm{~g} / 100 \mathrm{~cm}^{3}\right.$ of soil). The dead fine roots were observed mainly in $0-5 \mathrm{~cm}$ soil layer (0.041-0.043 g/100 $\mathrm{cm}^{3}$ of soil) when compared to $5-15 \mathrm{~cm}$ soil layer $\left(0.005-0.023 \mathrm{~g} / 100 \mathrm{~cm}^{3}\right.$ of soil).

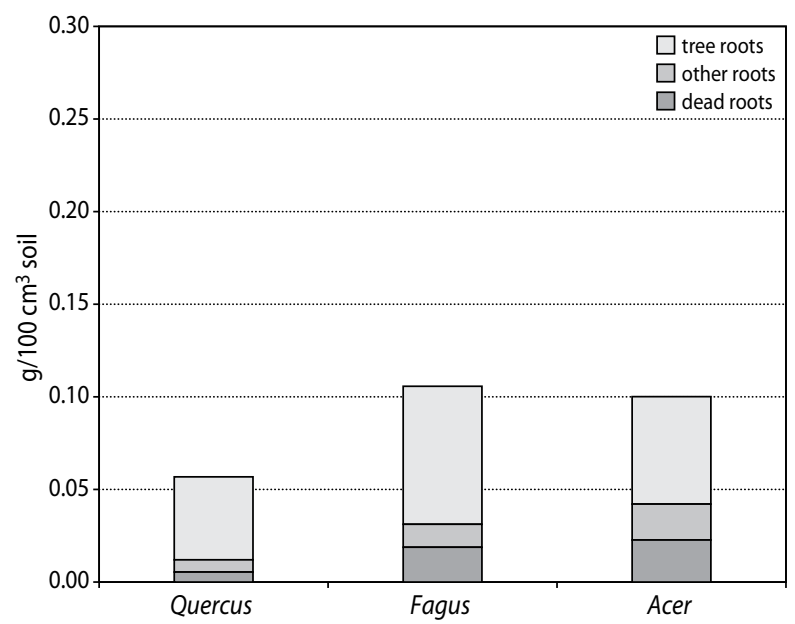

Figure 6. Mean fine root density $\left(\mathrm{g} / 100 \mathrm{~cm}^{3}\right.$ of soil) depending on tree biogroup (5-15 $\mathrm{cm}$ soil layer)

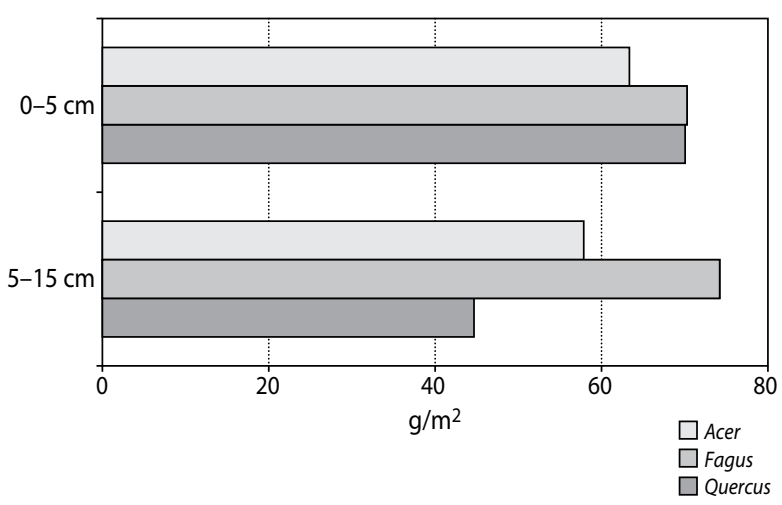

Figure 7. Vertical distribution of fine root biomass $\left(\mathrm{g} / \mathrm{m}^{2}\right)$ depending on tree biogroup (Acer, Fagus, Quercus) and soil layer $(0-5 \mathrm{~cm}, 5-15 \mathrm{~cm})$

The differences of the density of dead fine root between the biogroups were not statistically significant in $0-5 \mathrm{~cm}$ soil layer $(p>0.05)$, and significant $(H=14.2774$, $p=0.0008)$ in $5-15 \mathrm{~cm}$ soil layer. The significantly lowest density of dead fine roots was observed in Quercus biogroup when compared to Fagus $(p=0.0302)$ and Acer biogroup ( $p=0.0009)$. The vertical distribution of fine root of tree species $\left(63.35-70.28 \mathrm{~g} / \mathrm{m}^{2}\right)$ was similar in $0-5 \mathrm{~cm}$ soil layer, particularly in the case of beech 
trees and oak trees (Fig. 7). In the 5-15 cm soil layer there were found significantly smaller amounts of fine roots of oak $\left(44.67 \mathrm{~g} / \mathrm{m}^{2}\right)$ when compared to beech $\left(74.20 \mathrm{~g} / \mathrm{m}^{2}\right)$. Diversity $\left(H^{\prime}\right)$ of fine root biomass was on the same level in all tree biogroups $(1.50-1.56)$ in both soil layers (Fig. 8).

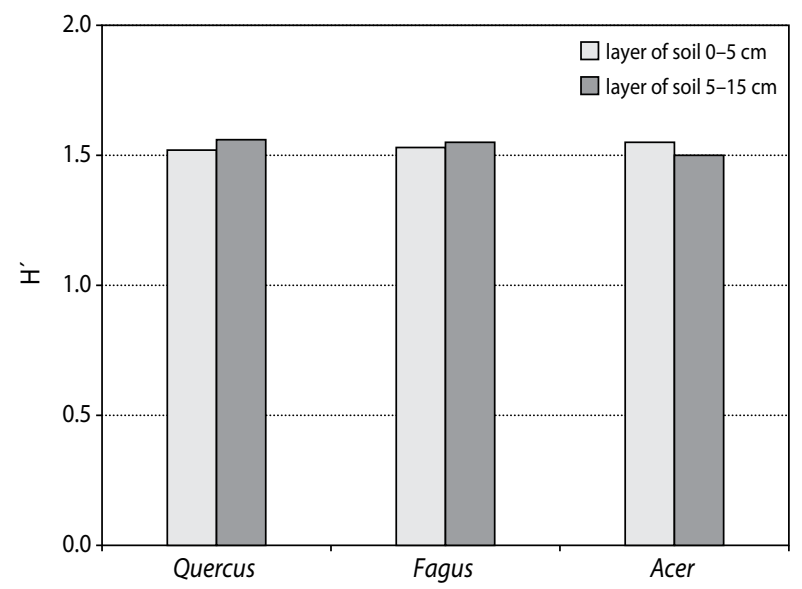

Figure 8. Diversity $\left(\mathrm{H}^{\prime}\right)$ of fine root biomass depending on tree biogroup and soil layer

\section{Climatic conditions}

During the decade prior to field observations conducted in 2010, mean annual temperatures ranged from $8.1^{\circ} \mathrm{C}$ to $10.4^{\circ} \mathrm{C}$. The vegetation seasons in the years

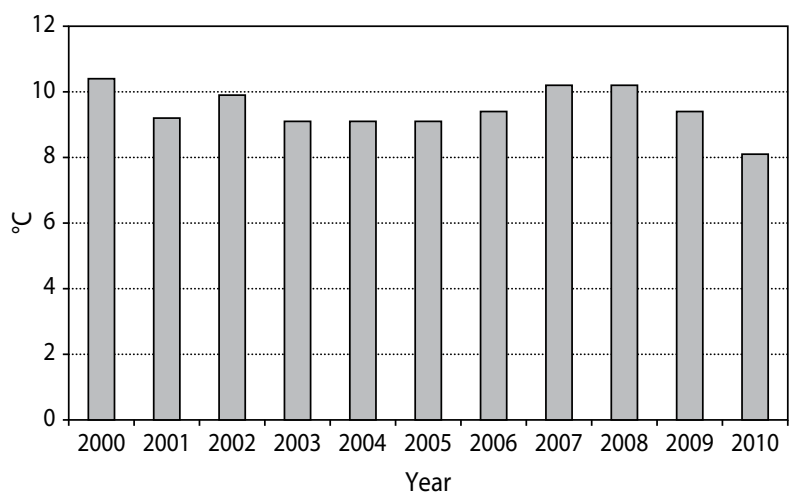

Figure 9. Mean annual temperature in the years 2000-2010 (Meteorological Station Wrocław)

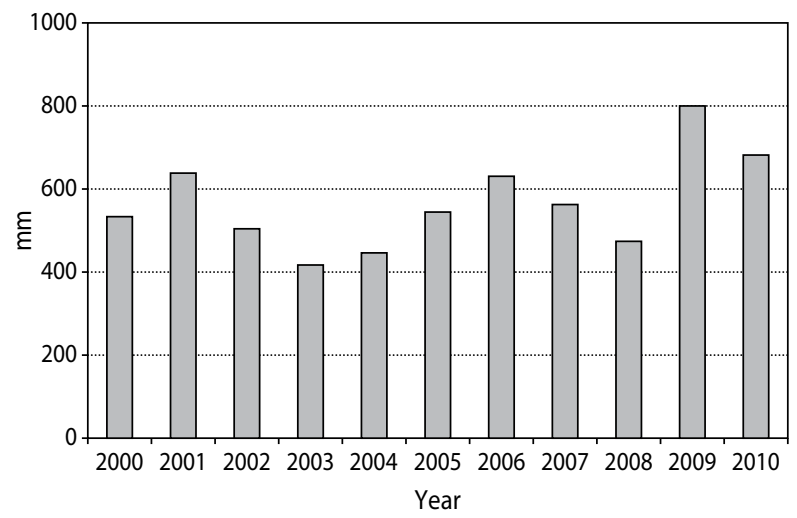

Figure 10. Mean annual precipitation in the years 2000-2010 (Meteorological Station Wrocław)

Table 1. Hydrometeorological index $(K)$ in vegetation seasons 2000-2010 (Meteorological Station Wrocław)

\begin{tabular}{|l|l|l|l|l|l|l|l|l|l|l|l|}
\hline \multirow{2}{*}{ Month } & \multicolumn{7}{|c|}{ Vegetative season } & \multicolumn{7}{l|}{} \\
\cline { 2 - 12 } & 2000 & 2001 & 2002 & 2003 & 2004 & 2005 & 2006 & 2007 & 2008 & 2009 & 2010 \\
\hline April & & & & & & & & & & & \\
\hline May & & & & & & & & & & & \\
\hline June & & & & & & & & & & & \\
\hline July & & & & & & & & & & & \\
\hline August & & & & & & & & & & & \\
\hline September & & & & & & & & & & & \\
\hline October & & & & & & & & & & & \\
\hline Mean & & & & & & & & & & & \\
\hline
\end{tabular}

\begin{tabular}{|c|c|c|}
\hline $\begin{array}{c}\text { Dry conditions } \\
(K \leq 1.3)\end{array}$ & $\begin{array}{c}\text { Optimal conditions } \\
1.3>K \leq 1.6\end{array}$ & $\begin{array}{c}\text { Humid conditions } \\
(K>1.6)\end{array}$ \\
\hline
\end{tabular}


2000, 2007, 2008 were the warmest and the year 2010 was considered as the coolest (Fig. 9). The mean total annual precipitation in 2000-2010 ranged from 417 $\mathrm{mm}$ to $800 \mathrm{~mm}$ (Fig. 10). The lowest precipitation (below $500 \mathrm{~mm}$ ) were observed in the years 2003, 2004 and 2008, and the highest - in 2009 and 2010 (800 $\mathrm{mm}$ and $681.8 \mathrm{~mm}$, respectively). In the period analyzed, based on the atmospheric drought index, there were identified $(K): 7$ dry years, 2 optimal years and 2 humid years (Tab. 1). The study year 2010 was ascertained as humid, with high precipitation during the months important in seasonal dynamics of fine root development in forest trees - May $(K=2.88)$ and September $(K=2.83)$.

\section{Discussion}

Multi-species plant structure reach stable equilibrium when competition between species is not as strong as that within species (Werner 1999). In tree biogroups, there can occur interactions supporting cooperation between trees (Zajączkowski 1994). According to Beyer et al. (2013) root competition can affect the structure of plant communities, through reducing root vitality or stimulating root growth. In the present study, the tested hypothesis was not confirmed, since the observed differences of root density in the topsoil $(0-5 \mathrm{~cm}$ and $0-15 \mathrm{~cm}$ ) between biogroups of mature trees were not statistically significant. However, beech trees showed the highest root density in $0-15 \mathrm{~cm}$ soil layer, especially the density of fine roots and roots $>10 \mathrm{~mm}$, when compared to oak trees and sycamore trees. Analogous results were obtained by Leborgeois and Jabiol (2002), who studied root development in beech and oak stands in France. According to the authors, depending on the conditions for growth, beech trees can develop roots in the topsoil more intensively when compared to oaks. The horizontal range of beech roots can be almost twice as greater as that in oak trees, whereas the vertical range - twice smaller. According to Mauer et al. (2007), there exists a significant relationship between horizontal and vertical root ranges and growth of the aboveground tree parts. The present study did not confirm such relationship, since beech and sycamore trees had considerably greater mean crown areas $\left(338.13 \mathrm{~m}^{2}\right.$ and $396.05 \mathrm{~m}^{2}$, respectively), when compared to oak trees $\left(145.08 \mathrm{~m}^{2}\right)$, and only beech trees showed comparatively more intensive root development in the topsoil $(0-15 \mathrm{~cm})$. The extensive root system allow for effective absorption nutrient and water by trees, consequently - adaptation to variable environmental conditions (Kozlowski and Pallardy 1997).

In the present study, there were found no statistically significant differences of the developing fine roots in the $0-5 \mathrm{~cm}$ soil layer between the tree species. However beech trees distinguished the highest fine root density $\left(0.216 \mathrm{~g} / 100 \mathrm{~cm}^{3}\right.$ of soil) in the soil layer $0-15 \mathrm{~cm}$ when compared to oak trees $\left(0.186 \mathrm{~g} / 100 \mathrm{~cm}^{3}\right.$ of soil $)$ and sycamore trees $\left(0.185 \mathrm{~g} / 100 \mathrm{~cm}^{3}\right.$ of soil). According to Leuschner et al. (2001) beech trees show better ability to develop fine roots when compared to oak trees. Under the conditions of strong competition, beech trees develop fine roots more intensely in deeper layers of the soil (Horn and Murach 2003)

The development of fine roots is connected with precipitation. According to Leuschner et al. (2004), in the regions with high annual precipitation, reaching even $1060 \mathrm{~mm} /$ year, the fine root biomass of beech is almost three times bigger when compared to the regions with annual precipitation $500-520 \mathrm{~mm}$. In the present study, climatic conditions observed in the years 2009-2010 can be considered as favorable $(K>1.6)$ for the development of fine roots of forest trees. The annual precipitation $(681-800 \mathrm{~mm} /$ year) was far greater than in the years 2000-2008 (528 mm/year). Also high precipitation in May-June and September-October was observed in the years 2009-2010, i.e. in the months considered as the periods of intense growth of the roots of forest trees in temperate areas (Breda et al. 1995). Thus, favorable conditions of root growth of forest trees in the vegetation seasons 2009-2010 can affect presented results.

\section{References}

Beckage B., Clark J.S. 2003. Seedling survival and growth of three forest tree species: the role of spatial heterogeneity. Ecology, 84 (7), 1849-1861.

Beyer F., Hertel D., Jung K., Fender A.C., Leuschner Ch. 2013. Competition effects on fine root survival of Fagus sylvatica and Fraxinus excelsior. Forest Ecology and Management, 302, 14-22. 
Breda N., Granier A., Barataud F., Moyne C. 1995. Soil water dynamics in an oak stand. I. Soil moisture, water potentials and water uptake by roots. Plant and Soil, 172, 17-27.

Brzeziecki B. 2000. Life-history strategies of forest tree species. Sylwan, 8, 5-14.

Bulletins of the State Hydrological and Meteorological Services. 2000-2010. IMGW.

Farfat D. 2011. The effect of habitat on European ash root growth in the topsoil layers. Leśne Prace Badawcze, 72, 109-114.

Forests in Poland 2012. 2013. CILP, Warszawa.

Horn A., Murach D. 2003. Verticale Feinwurzelverteilung und Hinweise auf interspezifische Wurzelkonkurrenz in Eschen/Buchen-Naturverjüngungen. Forstarchiv, 74, 46-52.

IPCC4. 2007. The Science of Climat Change (Australian Academy of Science), NOAA State of the Climate in 2012, NCDC NOAA.

Kozlowski T.T., Pallardy S.G. 1997. Growth control in woody plants. Academic Press, San Diego.

Lebourgeois F., Jabiol B. 2002. Enracinements compares du chene sessile, duchene pedoncule et du heter. Reflexions sur l'autecologie des essences. Revue Forestiere Française, 54 (1), 17-42.

Leuschner Ch., Hertel D., Coners H., Büttner V. 2001. Root competition between beech and oak: a hypothesis. Oecologia, 126, 276-284.

Leuschner Ch., Hertel D., Schmid I., Koch O., Muhs A., Hölscher D. 2004. Stand fine root and fine root morphology in old-growth beech forests as function of precipitation and soil fertility. Plant and Soil, 258 (1/2), 43-56.

Mayer H. 1992. Waldbau auf soziologisch-ökologischer Grundlage. 4. Aufl. G. Ficher Verlang, StuttgartJena-New York.

Macfall J.S., Johnson G.A., Kramer P.J. 1991. Comparative water uptake by roots of different ages in seedlings of loblolly pine (Pinus taeda L.). New Phytologist, 119, 551-560.
Mauer O., Pop M., Palátová E. 2007. Root system development and health condition of sycamore maple (Acer pseudoplatanus L.) in the air-polluted region of Krušné hory Mts. Journal of Forest Science, 53 (10), 452-461.

McClaugherty C.A., Aber J.D., Melillo J.M. 1982. The role of fine roots in the organic matter and nitrogen budgets of two forested ecosystems. Ecology, 63, 1481-1490.

Shannon C.E., Wiener W. 1949. The Mathematical Theory of Communication. University of Illinois Press, Urbana.

Santantonio D., Hermann R.K. 1985. Standing crop, production, and turnover of fine roots on dry, moderate, and well-watered sites of mature Douglas-fir in western Oregon. Annales des Sciences Forestieres, 42 (2), 113-142.

Sieljaninow G.P. 1966. Agroklimaticzeskaja karta mira. Leningrad.

Stykes M.T., Prentice I.C. 1995. Boreal forest futures: modeling the controls on tree species range limits and transient responses to climate change. Water, Air and Soil Pollution, 82, 415-428.

Vogt K.A., Vogt D.J., Palmiotto P.A., Boon P., O’Hara J., Asbornsen H. 1996. Review of root dynamics in forest ecosystems grouped by climate, climatic forest type and species. Plant and Soil, 187, 159-219.

Weiner J. 1999. Life and Evolution of the Biosphere. PWN, Warszawa.

Zajączkowski J. 1994. Tree biogroups in forest stands - possibilities and rationale for their use at thinnings. Prace IBL, Ser. A, 778, 5-38.

Zielony R., Kliczkowska A. 2012. Natural-forest regionalization of Poland 2010. CILP, Warszawa.

Ziernicka-Wojtaszek A. 2012. Comparison of selected indices for the assessment of atmospheric drought in the Podkarpackie province in the years 1901-2000. Woda Środowisko-Obszary Wiejskie, 12 (2), 365-376.

htpp://web.pages 